\title{
NECK AND SHOULDER PAIN AMONG MEDICAL SECRETARIES
}

\section{Sule Simsek*, Ozlem Senocale \\ Pamukkale University, Faculty of Physical Therapy and Rehabilitation, Turkey}

\begin{abstract}
Objectives: To determine the prevalence of musculoskeletal problems as well as the relationship between neck and shoulder pain and possible risk factors among medical secretaries.
\end{abstract}

Materials and Methods: 126 medical secretaries (mean age was $32.8 \pm 8.05$ years) included in this study. Standardized Nordic Musculoskeletal Questionnaire (NMQ) was used to analyse musculoskeletal symptoms. Work related factors are collected from mutual interview. Within the ergonomic assessment, work posture was examined by a physiotherapist with an observation of 10 minutes.

Results: 14 participants (11\%) were male and 112 participants (89\%) were female. According to NMQ, the incidence of neck pain was $65.9 \%$, whereas the incidence of shoulder pain was $59.5 \%$. The risk of neck and shoulder pain is increasing significantly in individuals who use computer more than 5 hours during the day. There was significant relation between non-ergonomical work posture and neck and shoulder pain.

Conclusion: Medical secretaries are one of the professions in the high risk group for neck and shoulder pain. It is important to make work posture and work environment proper for ergonomics.

Keywords: Medical secretary; Work Related Musculoskeletal Problems; Pain.

\section{INTRODUCTION}

Work-related musculoskeletal disorders comprises a wide spectrum. It defines the problems arising due to inflammatory and degenerative diseases [1]. Repetitive work activities, improper posture and mechanical load, duration of trunk flexion and rotation, psychosocial state and smoking are of the risk factors [2]. Particularly for the last 20-30 years, upper extremity pain prevalence increases gradually. According to World Health Organization (WHO, 1985), musculoskeletal problems due to working conditions have a multifactorial etiology involving beside physical conditions, work-related organizational, psychological, personal and sociocultural factors. Work-related risk factors are poor working posture, fast repetitive movements, challenging and overloading activities. In addition to these, among factors especially at neck and upper extremity; insufficient rest periods, overloading, misuse of keyboard, vibration, using of an upper extremity for a long time or by not getting support, low environmental temperature, psychosocial factors, sudden muscular load and frequently repeating of works requiring effort are considered $[3,4]$.

In literature, studies related to musculoskeletal pain are often encountered in health professional.

*Corresponding author:

Email: suleserefsimsek@yahoo.com

http://dx.doi.org/10.20530/IJTA $32 \quad 63-68$

ISSN 2320-138X (C) 2016
In health professional, it is confirmed that the prevalence of having pain at least in one area of the body is $90.3 \%$ [5]. Büker et al. determined this prevalence in physicans as $33.3 \%$, Tezel et al. indicated this as $90 \%$ in nurses $[6,7]$. In office workers this prevalence is seen have risen to $42 \%$ at head and neck, $34 \%$ at back area when compared to one year ago [8]. Today, because of advancement in technology and widespread using of computer, office workers complain mostly spinal pain caused by their static posture [9].

This study was planned to examine the prevalence of musculoskeletal problems as well as the relationship between neck and shoulder pain and possible risk factors among medical secretaries.

\section{MATERIALS AND METHODS}

This study was performed on 126 medical secretaries (112 Female, 14 Male) working at Izmir Dokuz Eylul University and having accepted to voluntarily participate. Individuals with the history of trauma and surgery involving of musculoskeletal system were excluded from the study. The participants read and signed the information consent form that was approved by a university institutional review board of the Faculty of Medicine of Dokuz Eylul University.

After recording demographical informations such as age, height, body weight, gender and exercise habits of medical secretaries who accepted to participate in the study, work-related risk factors (length of employment, weekly 
working hours, daily using computer) were recorded with the method of negotiation.

Within the ergonomic assessment, work posture was examined by a physiotherapist with an observation for 10 minutes. During observation, 10 different postures that leads to neck and shoulder pain are defined below.

During observation, the event of being stable in the one posture or repeating that posture 3 times for 1 minute was given 2 points, otherwise 1 point. 3 points was given according to the severity of the posture for 3 different postures (3th, 4th and 6th postures). Total score changes between 10-23 points. At the end of scoring, the group was averaged, posture under the mean score was defined to be good posture and the ones above the mean were poor posture [10].

1. Inadequate foot support

2. Inadequate back support

3. Flexion of the trunk $\geq 20$ 。

$\geq 60^{\circ}$

4. Rotation of the trunk $\geq 15^{\circ}$

5. Elevation of the shoulder

6. Flexion or abduction of the arms

$\geq 60$ • (Flexion)

$\geq 60$ (Abduction)

7. Flexion of the neck $\geq 20$ 。

8. Tilting backwards of the neck (Chin Forward)

9. Rotation of the neck $\geq 15$ 。

10. Arms over the level of elbows

The work site was visited, desk and chair used by the participants was assessed in terms of compliance with ergonomic standarts and personalized compatibility was assessed especially in the use of chair, desk and monitor.

A standardized questionnaire of Scandinavian Musculoskeletal System (The Nordic Musculoskeletal Questionnaire-NMQ) was applied to examine the analysis of musculoskeletal symptoms and work-related characteristics of these symptoms. The purpose in NMQ is to assess back, neck, shoulder and general musculoskeletal complaints with standardized questions. In NMQ, disorders on nine definite regions of a body (footankles, knees, thighs-hips, wrists-hands, waist, elbows, back, shoulders, neck) that have been apparent in the last 12 months and the last 7 days [11]. And in the special questionnaire section, there are questions relevant to whether severity of the symptoms, sick-leave during the preceding 12 months and to the case of tending to seek for a treatment.
A statistical software package (SPSS 10.0) was used to perform all analyses. Continuous and categorical data are reported as mean \pm standard deviation and number (percentages), respectively. Independent groups were statistically analyzed by using the Chi-square test. To determine risk factors of low back pain, the binary logistic regression method was used. Statistical significance was set at $p<0.05$.

\section{RESULTS}

The mean age of medical secretaries accepted to the study was $32.8 \pm 8.05$ years and the majority was female (89\%). Body Mass Index was calculated by the formula of body weight $(\mathrm{kg}) /$ height $\left(\mathrm{m}^{2}\right)$. It was determined that body mass index of $20.6 \%$ of the participants is over $25 \mathrm{~kg} / \mathrm{m}^{2}, 55.5 \%$ have worked for 6-10 years and $22.2 \%$ have been working in shifts (Table 1). According to NMQ

Table 1. Demographic Characteristics of the Medical Secretaries

\begin{tabular}{|c|c|c|}
\hline \multirow{2}{*}{$\begin{array}{l}\text { Age mean } \pm S D / m i n-\max \\
\text { Variables }\end{array}$} & \multicolumn{2}{|c|}{$32.08 \pm 8.05 / 21-48$} \\
\hline & $\mathbf{n}$ & $\%$ \\
\hline \multicolumn{3}{|l|}{ Gender } \\
\hline Male & 14 & 11 \\
\hline Female & 112 & 89 \\
\hline \multicolumn{3}{|l|}{ BMI $\left(\mathrm{kg} / \mathrm{m}^{2}\right)$} \\
\hline Under weight & 8 & 6.3 \\
\hline Normal weight & 92 & 73.1 \\
\hline Over weight & 26 & 20.6 \\
\hline \multicolumn{3}{|l|}{ Departments } \\
\hline İnternal Medicine & 56 & 44.5 \\
\hline Surgical Medicine & 22 & 17.5 \\
\hline Intensive Care & 22 & 17.5 \\
\hline Operating Room & 18 & 14.2 \\
\hline Emergency & 8 & 6.3 \\
\hline \multicolumn{3}{|l|}{ Lenght of employment } \\
\hline $1-5$ years & 24 & 19 \\
\hline $6-10$ years & 70 & 55.5 \\
\hline 11 years and over & 32 & 25.5 \\
\hline \multicolumn{3}{|l|}{ Work Shifts } \\
\hline No shift & 98 & 78.8 \\
\hline Be on Duty/Shift & 28 & 22.2 \\
\hline \multicolumn{3}{|l|}{ Site of Pain } \\
\hline Neck & 83 & 65.9 \\
\hline Shoulder & 75 & 59.5 \\
\hline
\end{tabular}

questionnaire results, it was determined that $65.9 \%$ of medical secretaries had neck pain and $59.5 \%$ has shoulder pain. When the number of painful days for the participants is examined, $50.6 \%$ of the ones with neck pain and $42.7 \%$ of the ones with shoulder pain have had pain in the last week. The pain in $62.7 \%$ of the ones with neck pain 
Table 2: Comparison of the variables of the participants with pain

\begin{tabular}{|c|c|c|c|c|c|c|}
\hline Variables & $\begin{array}{c}\text { Neck pain } \\
\mathrm{n}(\%) \\
\end{array}$ & ? 2 & $p$ value & $\begin{array}{c}\text { Shoulder pain } \\
n(\%)\end{array}$ & 圆 2 & p value \\
\hline \multicolumn{7}{|c|}{ The number of painful days } \\
\hline 1-7 days & $42(50.6)$ & & & $32(42.7)$ & & \\
\hline 8-30 days & $5 \quad(3.6)$ & & & $9(12)$ & & \\
\hline$>30$ days & $25(30.12)$ & & & $23(30.7)$ & & \\
\hline Daily & $13(15.7)$ & & & $11(14.7)$ & & \\
\hline \multicolumn{7}{|c|}{ The impact of the activity of pain } \\
\hline Yes & 31 (37.3) & & & $26(34.7)$ & & \\
\hline No & $52(62.7)$ & & & $49(65.3)$ & & \\
\hline Computer usage time & & 12.634 & $0.001 *$ & & 8.759 & $0.003^{*}$ \\
\hline$<5$ hours & $14(41.2)$ & & & $13(38.2)$ & & \\
\hline$\geq 5$ hours & $52(62.7)$ & & & $49(65.3)$ & & \\
\hline Work Posture Score & & 20.882 & $0.001^{*}$ & & 10.903 & $0.001 *$ \\
\hline Below the average & $30(46.9)$ & & & $29(45.3)$ & & \\
\hline Above the average & $53(85.5)$ & & & $46(74.2)$ & & \\
\hline
\end{tabular}

? 2: Chisquare test was used; *: Significant difference $(P<.05)$.

and $65.3 \%$ of the ones with shoulder pain doesn't prevent physical activities (Table 2).

It was observed that $41.2 \%$ of the medical secretaries who use computer less than 5 hours had neck pain and $38.2 \%$ of them had shoulder pain. It was observed that $75 \%$ of the medical secretaries who use computer more than 5 hours had neck pain and $67.4 \%$ of them had shoulder pain (Table 2). Analysing the computer usage time within groups; medical secretaries working with the computer for 5-8 hours daily were more susceptible to neck and shoulder pain compared with working for $1-4$ hours $(p<0.005)$.

The total score of the participant's work posture was calculated and the group average was come up with within the ergonomic assessment.
When medical secretaries with scores under and over the group average are compared, increase in the incidence of neck and shoulder pain in persons with scores over the group average is statistically significant $(p<0.005)$ (Table 2$)$. The distribution of work posture that causes neck and shoulder pain are described in Table 3.

Within ergonomic assessment, chair and desk used by the participants were complied with ergonomical standarts to a great extent. But it was seen that height of the chair and desk was not adjusted according to the participants.

Investigating the individual risk factors; age, gender, BMI, exercising habits and length of employment don't increase neck and shoulder pain. Work related risk factors including

Table 3: Distribution of work postures that causes neck and shoulder pain.

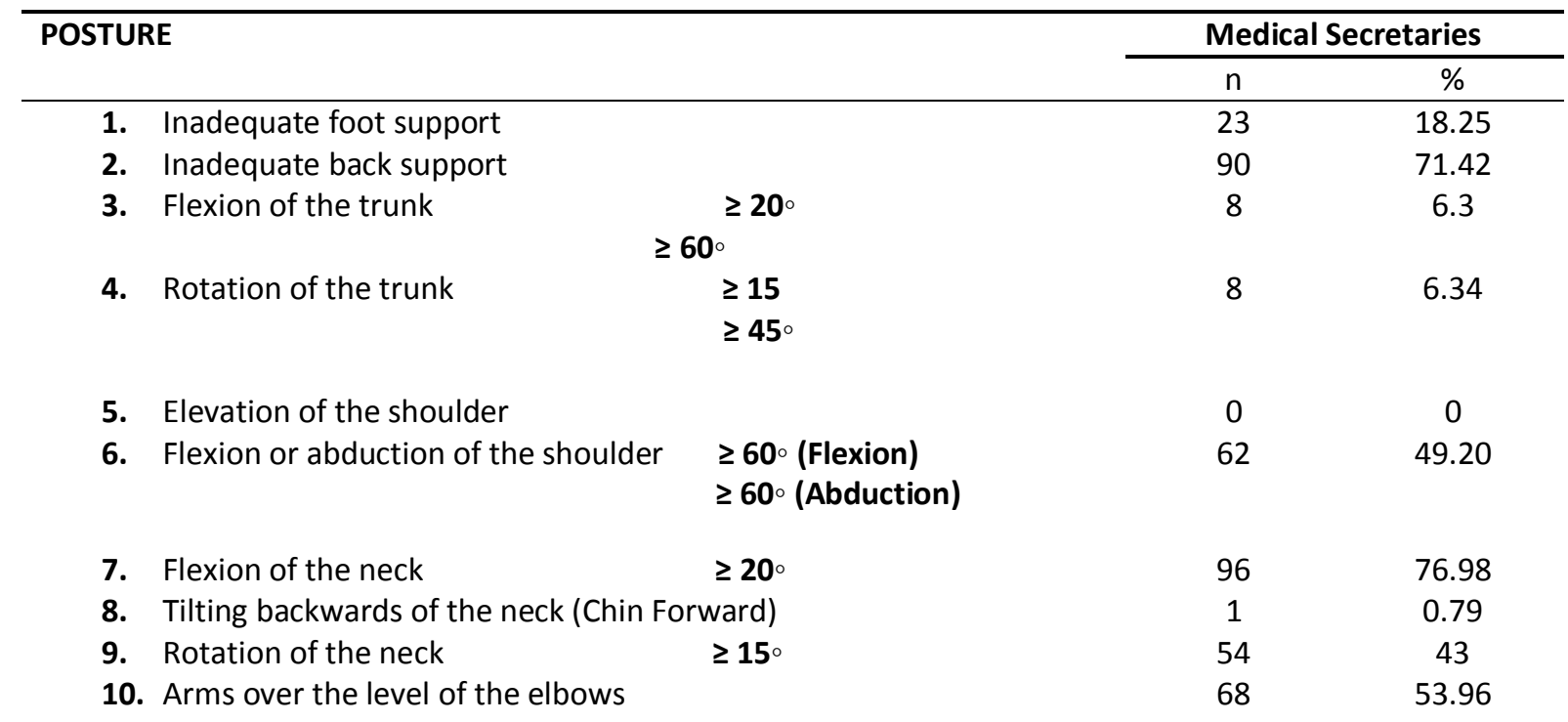


undesirable work posture and excessive use of computer throughout the day increases neck and shoulder pain. Undesirable work posture $(p=0.001)$ increases the risk of getting neck pain more than the duration of using computer $(p=0.046)$. It has been observed that undesirable work posture $(p=0.001)$ increases neck pain more than it does shoulder pain $(p=0.022)$. A 1 unit increase in work posture score increases neck pain 4.9 fold while it does shoulder pain 2.7 fold. A 1 unit increase in the duration of computer usage increases the risk of neck pain 2.5 fold while it does shoulder pain 2.4 fold (Table 4 ). female creates a risk in terms of musculoskeletal disorders in the literature [12-15], there are other studies supporting that muscle activity in sternocleidomastiod and upper part of trapezius in static posture doesn't change based on the gender [16]. The pain prevalence in females was observed to be higher in our study, but no statistically significant result was obtained, because $88.9 \%$ of the participants in the study are female. When the relation between age and pain prevalence in the literature is investigated, the number of studies is limited. Cımbız et al. indicated that an increase of one unit in age increases the pain generally $3.2 \%$

Table 4: Results from logistic regression model of risk factors for Neck and Shoulder pain

\begin{tabular}{lcccccc}
\hline Variable & $\mathbf{3}$ & $\begin{array}{c}\text { Neck pain } \\
\text { OR }\end{array}$ & \%95 Cl & $\mathbf{p}$ & $\begin{array}{c}\text { Shoulder pain } \\
\text { OR } \\
\text { (ExpB) }\end{array}$ & \% 95 Cl \\
\hline Age & & (ExpB) & & & 0.601 & $0.21-1.72$ \\
Gender & 0.767 & 0.845 & $0.39-3.60$ & 0.344 & 0.002 & $0.22-3.66$ \\
BMI & 0.581 & 0.674 & $0.37-6.01$ & 0.885 & 0.428 & $0.13-1.40$ \\
Exercise Habits & 0.267 & 0.493 & $0.59-7.07$ & 0.160 & 0.238 & $0.044-1.30$ \\
Lenght of employment & 0.346 & 0.473 & $0.45-10.66$ & 0.096 & 0.879 & $0.36-2.12$ \\
Computer usage time & 0.673 & 1.23 & $0.32-2.13$ & 0.774 & 0.874 \\
Work posture & $0.046^{*}$ & 2.569 & $1.02-6.50$ & $0.041^{*}$ & 2.436 & $0.96-6.18$ \\
\hline BMI: Body Mas & $0.001^{*}$ & 4.956 & $1.94-12.64$ & $0.022^{*}$ & 2.727 & $1.16-6.42$ \\
\hline
\end{tabular}

BMI: Body Mass Index; OR: Odds Ratio or beta value; p:significance level; *: Significant difference $(p<0.05)$;

$\mathrm{Cl}$ : Confidence Interval

\section{DISCUSSION}

This study was planned to examine the prevalence of musculoskeletal problems as well as the relationship between neck and shoulder pain and possible risk factors among medical secretaries. As a result of the study, $65.9 \%$ of the medical secretaries had neck pain and $59.5 \%$ of the medical secretaries had shoulder pain. Musculoskeletal pain is important because of being common and affecting professional life. In the study by which Çalık et al. examined musculoskeletal problems in office workers, the prevalence of neck pain was detected to be $67.1 \%$ and the prevalence of shoulder pain to be $50.6 \%$ [12]. Oha et al. have detected that the prevalence of neck pain in people using computer was $67.1 \%$ and the prevalence of shoulder pain to be $30 \%$ [13]. And in the study of Mohan et al. that conducted in academicians, the prevalence of neck pain was detected to be $44.7 \%$ and the prevalence of shoulder pain to be $40 \%$ [14]. Acording to the result of our study, $65.9 \%$ of medical secretaries were determined to have neck pain and $59.5 \%$ to have shoulder pain.

In our study, no significant relation was found between neck, shoulder pain and gender and age. While there are studies indicating that being fold [17]. Viikari et al. also indicated that the risk of having problems in musculoskeletal system at the neck and upper extremity with advancing age [18]. Yıldırım et al. indicate that age doesn't pose a risk for neck pain ${ }^{19)}$. $82 \%$ of the participants in our study are under 30 . Because of low average age of the participants, no significant relation between age and the pain could have been determined.

While obesity is indicated to be the reason for musculoskeletal pain and physical loading in daily activities in studies by which BMI is researched; in some studies, it is reported that overweight is not determinative for musculoskeletal pain $[20,21]$. In our study, it was found out that the ones with BMI of over $25 \mathrm{~kg} / \mathrm{m}^{2}$ had more prevalence of shoulder pain.

It has been determined that length of employment doesn't statistically pose a risk. Yıldırım et al. have similarly determined that the length of employment doesn't pose risk in the ones using computer [19].

The duration of using computer during the day was indicated to be a risk factor for neck pain in office workers in the literature [22,23]. According to our study, the duration of using computer being more than 5 hours poses a risk in terms of neck and shoulder pain. 
Office workers may be subjected to musculoskeletal pain due to their non-ergonomic working postures. Ariens et al. determined a significant relation between non-ergonomic rotation and bending movements of upper vertebra and neck pain [24]. That the computer on a desk being used for a long time is positioned improperly for the monitor, the positions of chair and desk might lead to shortening in soft tissues and strain, weakness, fatigue and pain in neck, back muscles in time [25]. In our study, improper work posture causing neck and shoulder pain have been determined to be working with neck flexion and rotation to a great extent, arm flexion and abduction to a higher than functional range of movement, non-ergonomic positioning of monitor, non-adjustment chair height according to individual and insufficient back support.

This study has shown that the musculoskeletal problems in medical secretaries are respectively on neck (65.9\%) and shoulder (59.5\%) areas. It has been determined that gender, age and the length of employment do not pose any risk for musculoskeletal disorders in our study. Working in a stable, non-ergonomic posture or repeating that posture frequently have been found out to increase neck and shoulder pain. The limitation of this study is that the number of participants involved in the study was low.

It is of great importance that medical secretaries may protect their body mechanics while working, be aware of the risk factors causing musculoskeletal pain, these problems be determined at their early stages and prevented from becoming chronic. We think that necessary studies should be done to avoid and reduce these problems especially in people working on a desk for a long time. Within this context, it is important to make work posture and work environment proper for ergonomics.

\section{Conflict of Interest and Financial Statement}

Author(s) don't have any conflict of interest in any case relevant to the article.

No financial support was acquired pertaining to the study.

\section{REFERENCES}

1- Buckle PW, Jason Devereux J. The nature of workrelated neck and upper limb musculoskeletal disorders. Applied Ergonomics. 2002 May;33(3):207-17. Available from: http://dx.doi.org/10.1016/s0003-6870(02)00014-5.
2- Hviid Andersen J, Kaergaard A, Frost P, Frølund Thomsen J, Peter Bonde J, Fallentin N, et al. Physical, Psychosocial, and Individual Risk Factors for Neck/Shoulder Pain With Pressure Tenderness in the Muscles Among Workers Performing Monotonous, Repetitive Work. Spine. 2002 Mar;27(6):660-7. Available from: http://dx.doi.org/10.1097/00007632-20020315000017.

3- Kuorinka I, Jonsson B, Kilbom A, Vinterberg $H$, Biering-Sørensen $F$, Andersson $G$, et al. Standardised Nordic questionnaires for the analysis of musculoskeletal symptoms. Applied Ergonomics. 1987 Sep;18(3):233-7. Available from: http://dx.doi.org/10.1016/0003-6870(87)90010-x.

4- Tsai SP, Gilstrap EL, Cowles SR, Waddell LC Jr, Ross CE. Personal and job characteristics of musculoskeletal injuries in an industrial population. J. Occup.Med. 1992; 34(6) : 606-12.

5- Dıraçoğlu D. Sağlık personelinde kas-iskelet sistemi ağrıları. Türkiye Klinikleri J Med Sci. 2006; 26(2):132-9.

6- Buker N, Aslan E, Altuğ F, Cavlak U. Hekimlerde kasiskelet sistemi problemlerinin analizi. Dumlupınar Üniv Fen Bil Enst Derg. 2006;10:163-70.

7- Tezel A. Musculoskeletal complaints among a group of Turkish nurses. International Journal of Neuroscience. 2005 Jan;115(6):871-80. Available from:

http://dx.doi.org/10.1080/00207450590897941.

8- Fredriksson $K$, Alfredsson $L$, Koster $M$, Thorbjornsson CB, Toomingas A, Torgen $M$, et al. Risk factors for neck and upper limb disorders: results from 24 years of follow up [published erratum appears in Occup Environ Med 1999 May;56(5):358]. Occupational and Environmental Medicine. 1999 Jan 1;56(1):59-66. Available from: http://dx.doi.org/10.1136/oem.56.1.59.

9- Mackinnon SE, Novak CB. Repetitive strain in the workplace. The Journal of Hand Surgery. 1997 Jan;22(1):2-18. Available from: http://dx.doi.org/10.1016/s0363-5023(05)80174-1.

10- Kamwendo K, Linton SJ, Moritz U. Neck and shoulder disorders in medical secretaries-Part I. Pain prevalence and risk factors. Scand J Rehab Med. 1991;23(3):127-33.

11- Crawford JO. The Nordic Musculoskeletal Questionnaire. Occupational Medicine. 2007 Apr 16;57(4):300-1. Available from: http://dx.doi.org/10.1093/occmed/kqm036.

12- Calik BB, Atalay OT, Baskan E, Gokce B. Analyzing musculoskeletal system discomfort, work interference and risk factors of office workers with computer users. MÜSBED.2013;3(4):208-214. Turkish. doi:10.5455/musbed.20131215111048 
13- Oha K, Animägi L, Pääsuke $M$, Coggon D, Merisalu E. Individual and work-related risk factors for musculoskeletal pain: a cross-sectional study among Estonian computer users. BMC Musculoskelet Disord. 2014;15(1):181. Available from: http://dx.doi.org/10.1186/1471-2474-15181.

14- Mohan V, Justine $M$, Jagannathan $M$, Aminudin SB, Johari SHB. Preliminary study of the patterns and physical risk factors of work-related musculoskeletal disorders among academicians in a higher learning institute. Journal of Orthopaedic Science. 2015;20(2):410-7. Available from: http://dx.doi.org/10.1007/s00776-014-0682-4.

15- Côté P, Cassidy DJ, Carroll LJ, Kristman V. The annual incidence and course of neck pain in the general population: a population-based cohort study. Pain. 2004 Dec;112(3):267-73. Available from:

http://dx.doi.org/10.1016/j.pain.2004.09.004.

16- Ng D, McNee C, Kieser J, Farella M. Neck and shoulder muscle activity during standardized workrelated postural tasks. Applied Ergonomics. 2014 May;45(3):556-63. Available from: http://dx.doi.org/10.1016/j.apergo.2013.07.012.

17- Cımbız A, Uzgören N, Aras Öztürk S, Elem E, Aksoy CC. Kas iskelet sisteminde ağrıya ait risk faktörlerinin lojistik regresyon analizi ile belirlenmesi: pilot çalışma. Fizyoter Rehabil. 2007;18(1): 20-27.

18- Viikari-Juntura E. Longitudinal study on work related and individual risk factors affecting radiating neck pain. Occupational and Environmental Medicine. 2001 May 1;58(5):34552. Available from: http://dx.doi.org/10.1136/oem.58.5.345.
19- Yıldırım Y, Gelecek N, Özcan A, Altın Ö, Kılıç M. Bilgisayar kullananlarda boyun ağrısına etki eden risk faktörleri. Fizyoter Rehabil. 2004;15(3): 114119.

20- Webb R, Brammah T, Lunt M, Urwin M, Allison T, Symmons D. Prevalence and Predictors of Intense, Chronic, and Disabling Neck and Back Pain in the UK General Population. Spine. 2003 Jun;28(11):1195202. Available from: http://dx.doi.org/10.1097/01.brs.0000067430.4916 9.01 .

21- Tsuritani I, Honda R, Noborisaka $Y$, Ishida $M$, Ishizaki M, Yamada Y. Impact of obesity on musculoskeletal pain and difficulty of daily movements in Japanese middle-aged women. Maturitas. 2002 May;42(1):23-30. Available from: http://dx.doi.org/10.1016/s0378-5122(02)00025-7.

22- Johnston V, Souvlis T, Jimmieson NL, Jull G. Associations between individual and workplace risk factors for self-reported neck pain and disability among female office workers. Applied Ergonomics. 2008 Mar;39(2):171-82. Available from: http://dx.doi.org/10.1016/j.apergo.2007.05.011.

23- Widanarko B, Legg S, Stevenson M, Devereux J, Eng $A$, Mannetje A ' $t$, et al. Prevalence of musculoskeletal symptoms in relation to gender, age, and occupational/industrial group. International Journal of Industrial Ergonomics. 2011 Sep;41(5):561-72.

24- Ariëns GA, van Mechelen $W$, Bongers PM, Bouter LM, van der Wal G. Physical risk factors for neck pain. Scand J Work Environ Health. 2000 Feb;26(1):7-19.

25- Calik BB, Yagci N, Gursoy S, Zencir M. Upper extremities and spinal musculoskeletal disorders and risk factors in students using computers. Pak J Med Sci. 2014;30(6):1361-6. 